\title{
Lichens Mentioned by Pedanios Dioscorides
}

\author{
Mustafa Yavuz \\ Isiklar Air Force High School, Department of Science, 16039, Teleferik, Bursa, Turkey \\ E-mail: mustafay007@gmail.com
}

KEYWORDS Parmelia sp. Materia Medica. Ethnobotany. Lichenized Fungi

ABSTRACT Lichens are included in the classification system of fungi and have been used in medicine, pharmacy and industry from antiquity to present day in the treatment of various diseases. In this study, Peri Hyles Iatrikes of Dioscorides has been investigated and evaluated from lichenological point of view. It is found that, Dioscorides mentions about medical properties and uses of probable Parmelia species such as P. saxatilis (L.) Ach or P. sulcata Taylor.

\section{INTRODUCTION}

\section{Dioscorides and His Materia Medica}

Pedanius Dioscorides probably lived between 40 - 90 AD, in the time of the Roman Emperors Nero and Vespasian. He was born in Anazarbos (Anazarba or Anavarza near Dilekkaya Village, Kozan, Adana, Turkey) as a Cilician Greek within the Roman Empire. He was a botanist or a physician in the army and saw service with the Roman legions in Greece, France, Italy and Turkey. This military service provided him many opportunities to study diseases, collect and identify medicinal plants, and discover some other healing materials.

He was a contemporary of Gaius Plinius Secundus. However, there is no evidence if they ever met or they have read each other's book. Dioscorides probably wrote his great herbal between $65-75 \mathrm{AD}$, and was regarded as the ultimate authority on plants and medicine for a long time.

The descriptions of plants in his book were often adequate for identification, including methods of preparation, medicinal uses, and dosages. His herbal which is originally named as "Peri Hyles Iatrikes" meaning "Regarding Medical Matters", translated as "Kitab-al Hashaish" in Arabic will be mentioned as "De Materia Medica" hereby as it is in Latin. The oldest codex of this book is "Codex Constantinopolitanus" devoted to Juliana Anicia, the Byzantine Princess and daughter of Anicius Olybrius, the Emperor. This codex was written in Constantinapolis (Istanbul) at Prodromos Petra Monastery, later was sold to Austria by son of Musa bin Hamon, Royal Doctor of Kanuni Sultan Süleyman and is still preserved at Österreichische National Bibliothek (National
Library of Austria), Wiener Dioskurides, Med. Gr. 1 (Baytop 1997, 2000).

De Materia Medica consists of five books, divided by subjects; $1^{\text {st }}$ Book: aromatics, oils, oinments, trees, liquors, gum and fruits; $2^{\text {nd }}$ Book: animals, cereals, milk and milk products, herbs, spices, grains, resins, oils, ointments, trees and fruits; $3^{\text {rd }}$ Book: roots, weeds, herbs, juices, seeds; $4^{\text {th }}$ Book: roots, weeds, herbs; $5^{\text {th }}$ Book: drinks, vines, wines and inorganic materials (Baytop 2000; Osbaldeston 2000).

De Materia Medica was translated from Greek to Assyrian and from Assyrian to Arabic no later than IX. century (Baytop 1984). In first half of IX. century, it was translated from Greek to Assyrian by "Cebrail bin Buhtiyeshu" (Gabriel bin Bochtishô) and soon, from Greek and Assyrian to Arabic by "Istefan bin Basil" (Etienne Stephanos). This translation was revised by "Hunayn Ibn Ishaq" (also known as Joannitus). A codex of this translation is still kept at Paris Bibliothèque Nationale Suppl. No: 1067 while the others are at Istanbul Süleymaniye Library, Collection Ayasofya (Ünver 1941). The text concerned to this paper is in Book 4, under Chapter IV. 54 which begins in Greek as "Lichens growing on rocks", in Arabic as "Tetter of rocks" and in Latin as Lichen des roches, Lichen petraeus latifolium (Wessely 1906; Basmadjian 1938).

Other translations in Latin and Spanish including many comments were made by "Andres de Laguna"; in Latin and Italian by "Pietro Andrea Matthioli" during the end of XV. and beginning of XVI. centuries. Matthioli's Latin translations were translated in Ottoman Turkish by "Osman bin Abdurrahman" of Beograd in 1777. However, this book has not been transcribed in modern Turkish yet (Laguna 1555; Matthioli 1568; Baytop 2000). 
In the XVI. century, Latin translations including the Greek text of De Materia Medica were published by Du Ruel (1549) and Iani Antoni Saraceni (1598).

In 1655 John Goodyer made an English translation from an early printed Latin version, and Robert T. Gunther (1933) edited this translation. Today, there is a comprehensive English translation by Tess Anne Osbaldeston (2000). An earlier German translation by Julius Berendes from 1902 and an anonymous Spanish translation are available on some web resources (WEB01, WEB02).

\section{Lichens in General}

Lichens are symbiotic associations of a fungus with a photosynthetic partner either a member of chlorophyta or cyanobacteria. Some lichens have a shape of leaves (foliose lichens), others cover the substrates like a crust (crustose lichens) or they seem such as shrub or a fibril (fruticose lichens). According to the substrata, where they grow on, lichens are considered in three divisions as Saxicolous*, Terricolous ${ }^{* * *}$ and Epiphytic. ${ }^{* * *}$ Currently, lichens are included in the classification system of fungi under Ascomycota (Nash 2008).

Lichens have been used in medicine, pharmacy and industry from antiquity to present day in the treatment of various diseases like alopecia, arthritis, constipation, infection, kidney diseases, leprosy, pharyngitis rabies, worm and infestation (Richardson 1991; Malhotra et al. 2008). Medicinal uses of some lichens in folk and traditional medicine are given in the studies of Cobanoglu and Yavuz (2003), Malhotra et al. (2008) and Yavuz and Cobanoglu (2010). Lichens produce a wide range of bioactive secondary metabolites, referred to as "Lichen Substances" (Huneck and Yoshimura 1996).

Lichen metabolites exert a wide variety of biological actions including analgesic, antibiotic, anti-inflammatory, antimicrobial, antimycobacterial, antiproliferative, antipyretic, antitumor, antiviral, cytotoxic and immunomodulator effects. Even though these manifold activities of lichen metabolites have now been recognized, their therapeutic potential has not yet been fully explored and thus remains pharmaceutically unexploited (Müller 2002; Malhotra et al. 2008).

Interestingly enough, the word "Lichen" is derived from Greek word "Leikhen - Leprous" and refers to use of lichens in treating skin diseases due to their peeling-skin appearance (Malhotra et al. 2008).

\section{METHODOLOGY}

In this study, a number of documents, books and digital resources of De Materia Media and its translations are examined by means of lichenology. The text about lichens from various translations of De Materia Medica are investigated and translated to English and comparatively studied with the original Greek one. Chemical data on some lichen species and metabolites are given in order to clarify and refine their uses under medicinal purposes.

\section{RESULTS}

\section{Dioscorides in Oriental Translations}

Arabic translation of De Materia Medica, named as: "Kitâb el-Hashaish li Dîskurîdus elAnazarbî (Book of Spices from Dioscorides of Anazarba)" is in Istanbul Süleymaniye Library, Collection Ayasofya, with the numbers 3702, 3703 and 3704 (Cobanoglu and Yavuz 2003). The volume indicated as Ayasofya 3703 was probably written in 1224, and on page 49 (folio 25 recto), there is a chapter about lichens: Hazaz el-Sahr, Lîhen kutrun (Fig. 1). In volume of Ayasofya 3702, lichens are mentioned on page 167 (folio 84 verso) under the chapter Lîhen kutrun. An English translation of these chapters is given below:

About Lichen on Rocks: It is Hazaz el-Sahr, grows over rocks. When smeared over flowing blood, it stops bleeding; heals the inflammations. If mixed with honey, it is useful against jaundice and heals inflammations of the tongue.

The Andalucian Herbalist, Abu Muhammed bin Abdallah bin Ahmed al Maliki (1190 1248), shortly known as "Ibn-i Baytar" in oriental, and as "Ibn al Baithar" in occidental studies; mentioned works of ancient physicians and herbalists such as Dioscorides, Galenus, and lately Ibn-i Sina (Avicenna) in his great work: "Kitab al Jami fi'l Adviyyat al Mufradat ve'l Aghdiyyat," A Comprehensive Book on Simple Drugs and Foods, well- known as "Mufradat of Ibn al Baithar". His book consists of four parts including many plants, animals and some minerals given in alpha-numerical order of Arabic 


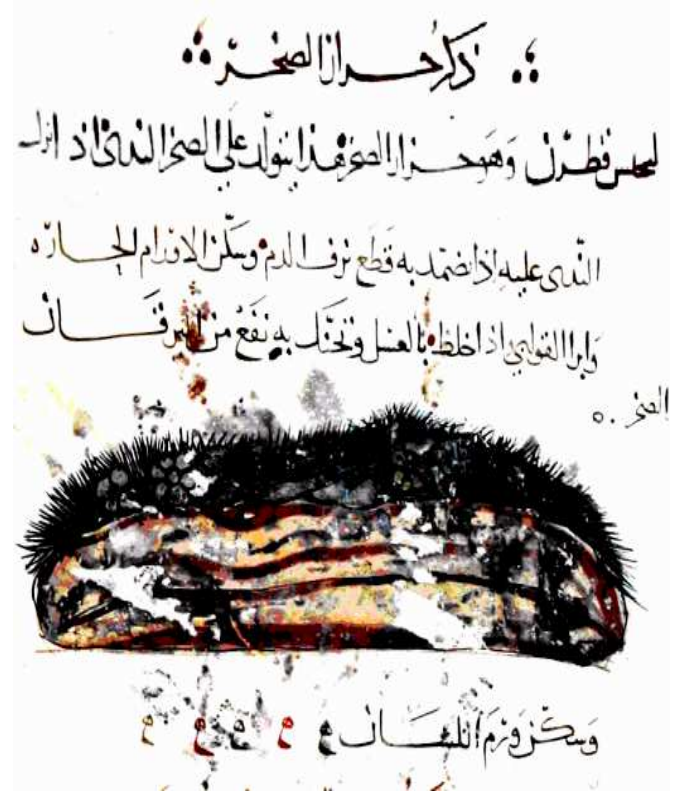

Fig. 1. Lîhen kutrun from Codex Ayasofya 3703 (C) By courtesy of Süleymaniye Library, Ýstanbul)

Alphabet. This book was published in four volumes in Cairo in 1874; translated to German by J. V. Sontheimer in 1840 and to French by Lucien Lerclerc as "Traité des Simples par Ibn al Beïthar" in 1877. There are also various Turkish translations from XIV. - XVII. centuries (Yildirim 2003).

Today, in Istanbul Süleymaniye Library, Collection Ayasofya, number 3608, we find the Arabic version and in Hüsrev Pasa Collection, number 476, a Turkish translation of "Mufradat of Ibn al Baithar" indirectly including the text about lichens from De Materia Medica (Cobanoglu and Yavuz 2003):

Ayasofya 3608: Hazaz es-Sahr (Tetter of Rock); Dyskurydus, Book iv., Grows on rocks, stops blood flowing, calms reddish inflammations. If mixed with honey and applied in body, is good for Jaundice. Soothes swollen tongue".

Hüsrev Pasa 476: Hazaz es-Sahr; Tas kinasidir. Eger yaku etseler issi sislere ve kan cikan yerlere ve demregüye vursalar begayet fâide ide. Eger balla karisdirsalar gargara itseler yerkana fâide ide, ve dil sisini sâkin ide, eger damaga yapisdirsalar dahi eyle ide". Hazaz es-Sahr: It is Henna of Rocks. If applied as plaster on swollen and bleeding inflammations and on impetigo, it is quite useful. If mixed with honey and gargled, is useful for jaundice and soothes swollen tongues even if it is put on palate".

\section{Dioscorides in Occidental Translations}

The Ancient Greek texts in translations of Du Ruel and Saraceni, are transcribed in Latin alphabet (!) with an English translation below:

Peri Leikhinos: Leikhen o epi ton petron, oi Bryon kalousi, Bryon esti prosekhomenon tais endrosois petrais. Touto kataplasthen aimorragias istesi kai phlegmonas paraiteitai kai leikhenas therapeuei. Ophelei de kai ikterikous meta melitos diakhriomeuon. Stomatos de kai tes glottes reumatismous paraiteitai.

About Lichens: Lichen, which grows on stones, some (people) name it moss (bryon), which adheres to dry rocks. It stops bleeding when put upon, drives inflammations away and heals impetigo. It helps the jaundiced when smeared with honey and also drives away the mouth and tongue rheumatism.

The text in Greek is same in both Du Ruel's and Saraceni's works; however there are some differences between the text in Latin:

Lichen Cap LIII: Lichen, qui saxis est familiaris, aliquibus bryon appellatur: asperginosis petris adharet, vt muscus. Is illitus sanguinis profluuia sistit, inflammationes arcet, impetigini medetur. Iuuat regio morbo correptos, cum melle illitus: oris et lingua defluxiones inhibet. Lichen: The lichen, which grows on stones, is sometimes called Bryon. It adheres to stones like the moss. If you smear over the flowing of the blood (it) stops, keeps away the inflammations, heals the impetigo. (When) snatched up, it helps to the royal sickness, smeared over with the honey: restrains flowing of the mouth and the tongue (Du Ruel 1549).

De Lichene Liber IV Cap LIII: Lichen qui petris innascitur, et aliquibus bryon apellatur, ceu muscus est roscidis petris inherens. Is impositus sanguinis eruptiones sistit, inflammationes lenit, ac impetigini medetur. Inuat et arquatos cum melle illitus: caterum defluxionibus oris ac lingua succurrit. About Lichen: The lichen which grows on rocks -as in the same way the Moss exists and fastens on wet rocks- is sometimes called Bryon. It stops blood flow (if) you put it upon; calms inflammations and also heals impetigo. It helps jaun- 
diced (ones) when smeared over with honey: (On) the other (hand, it) runs to the aid of flowing at mouth and tongue (Saraceni 1598).

English translation by Robert T. Gunter (1933) in "The Greek Herbal of Dioscorides" is given below:

Leichen: Lichen, that which grows upon rocks, but some calls it Bryon, is a moss sticking to moist rocks. This being laid on doth stop ye fluxes of blood, \& doth assuage inflammations, \& doth heal Lichenas (Probably Lichen planus, a papulosquamous eruption on skin) \& it doth help the Ictericall being laid on with honey, and doth help also the rhumes of ye mouth, \& ye tongue (Gunter 1933).

Same text from Tess Anne Osbaldeston's (2000) translation:

Lichen grows on rocks and is also called bryon. It is a moss sticking to moist rocks. This is applied to stop discharges of blood, lessen inflammation, and heal lichen (papular skin disease), and applied with honey it helps jaundice. It also helps the fluids of the mouth and tongue (saliva).

Osbaldeston (2000) also suggests many terms for "Leichen" of Dioscorides: Alectoria jubata, Hepatica (Fuchs), Hepatica fontana (Bauhin), Horse Hair Lichen, Lecanora esculenta, Lichen petraeus latifolius, Lichen, Manna Lichen, Marchantia polymorpha (Linnaeus), Parmelia saxatilis, Rock Hair Moss.

German translation by Julius Berendes (1902), which is available on an internet source (WEB02), is as follows:

Flechte: Das auf den Felsen wachsende Leichen - Einige nennen es Bryon - ist ein an behauten Felsen hängendes Moos. Als Umschlag stillt es Blutungen, besänftigt Entzündungen und heilt Flechten. Mit Honig aufgestrichen heilt es die Gelbsucht und beruhigt Rheuma des Mundes und der Zunge. Lichen: The growing bodies on the rocks - some call it Bryon - are sticking on moist rocks. When laid on, it stops bleeding, calms the inflammations and heals Lichenas. If mixed with honey it cures jaundice and soothes rheumatism of the mouth and tongue.

An interactive edition of De Materia Medica is available at the website of Salamanca University, with picture of a lichen which is a probable Ramalina sp. species. This work is a result of a project coordinated and edited by Antonio López Eire and translated by his team (WEB01).
Del liquen (leikhen): Liquen que crece sobre las piedras. [Otros lo llaman 'musgo'(brýon)] Es un musgo adherido a las piedras húmedas. Aplicado como emplasto, restaña la hemorragia, alivia las inflamaciones y cura las excrecencias cutáneas. Es útil también para los que padecen de ictericia y, untada la boca y la lengua con él, mezclado con miel, alivia las fluxiones. Lichen grows on the rocks. [Others call it "moss" (Bryon)] Moss is adhered to the wet rocks. Applied as a poultice, staunch the bleeding, relieves inflammation and heals the skin growths. It is also useful for those suffering from jaundice and when smeared. Mixed with honey, it relieves fluxions of mouth and tongue.

In web source of National Library of France (Bibliothèque Nationale de France, Département des Manuscrits, Division Occidentale, Cote: Grec 2179), another drawing of a lichen is given with Greek text of Materia Medica (WEB03).

\section{DISCUSSION}

In this study, Dioscorides' Peri Hyles Iatrikes has been investigated and evaluated from lichenological point of view. Arabic, English, German, Latin, Spanish and Turkish translations were compared to the original Greek text mentioning the uses of lichens in ancient medicine. It is found that, Dioscorides mentions about a botanical drug in chapter "IV.54 Leikhen" which is "Lichen" or "Lichenized Fungi" under the Kingdom Fungi, in today's taxonomy. After a brief description of lichens, he gives examples of some medical uses. There is not enough or satisfactory morphological evidence in order that one could taxonomically identify the lichen species mentioned in De Materia Medica. However, it is obvious that, Dioscorides describes a lichen species growing among mosses on rocks (saxicolous), since he mentions Mosses in a separate chapter "II.20. Bryon".

In his De Materia Medica, Dioscorides prescribes that lichens:

- $\quad$ stop bleeding,

- calm inflammations,

- $\quad$ heal Lichenas (probably the Lichen planus disease),

- $\quad$ cure Jaundice and

- relieve rhumes of mouth and tongue.

Dioscorides' prescriptions are compared to the Potential Uses of some Lichen Metabolites reported in the relevant literature (Table 1). 
Table 1: Potential uses reported for lichen metabolites

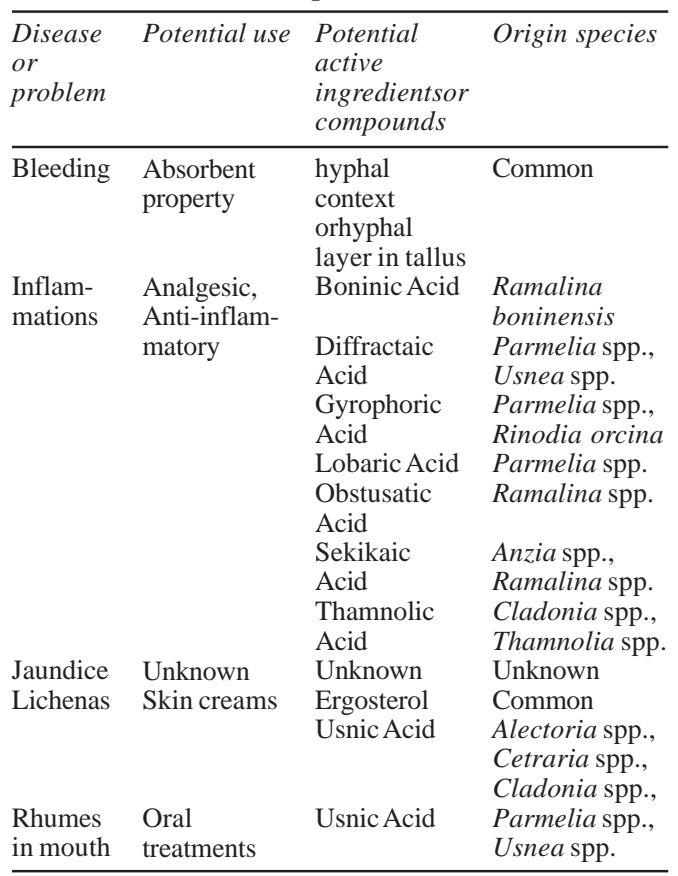

Bleeding: Produced by fungal partner, lichens have an absorbent hyphal tallus which may stop bleeding or stop flowing of blood when the lichen is put upon wounds.

Inflammations: involving inflammations, leukotrienes and prostaglandins both have numerous and important biological functions. Repression of either leukotrienes or prostaglandins has beneficial anti-inflammatory effects (Marx 2001). Several lichen metabolites cause decreased level of these compounds. For instance, Diffractaic, Gyrophoric, Lobaric, Obstusatic, Sekikaic and Thamnolic Acids exhibited interesting activity (Kumar and Müller 1999, 2000). In Aslan et al. (1999, 2002), and Dülger et al. (1997) studies, lichen species containing Usnic Acid are reported to have anti-bacterial effects on Gram Positive Bacteria. Thus, one can theoretically explain in general, how lichens could relieve rhumes of mouth and tongue, calm inflammations and heal Lichen planus. Moreover, Chevallier (1996) reports that Usnea filipendula Stirt was used in former Soviet Union for cuts and wounds.

Jaundice: We do not know any studies about lichens to treat jaundice. However, an orangeyellowish species Xanthoria parietina, due to its color, has been used against jaundice in traditional medicine since antiquity (Llano 1950).

Lichenas: Facial acne control creams containing lichen antibacterial agents such as Usnic Acid or Lichesterinic Acid have been developed (Higuchi et al. 1993). These moisturizing creams with different levels of Usnic Acid, were tested for antimicrobial activity against bacteria, yeasts and molds (Seifert and Bertnard 1995). However, use of these products is not widespread in light of the potential allergenic reaction certain people have to this natural product (Romagni and Dayan 2002).

Rhumes in mouth: Usnea spp. are valued for demulcent properties and finds use for mild inflammation of the oral and pharyngeal mucosa. Usnic Acid has been tested in toothpaste for preventation of plaque and cavity formation (Ferrari et al. 1988) revealing that it effectively inhibited the growth of Gram Positive Bacteria such as Streptococcus mutans, the primary pathogenic micro-organism causing dental and some oral problems. Usnic Acid is also effective as a prophylactic treatment against dental plaque (Romagni and Dayan 2002).

\section{CONCLUSION}

Genus Parmelia Ach was used in ancient or traditional medicine, as well as many other genera. Lichens produce specific lichen substances; however some of metabolites are common among species of same genus. As it is figured out in Table 1, genus Parmelia Ach. commonly contains Diffractaic, Gyrophoric and Lobaric Acids (Romagni and Dayan 2002) as well as atranorin, chloroatranorin (grey species), and usnic acid (greenish-yellow species) in cortex; orcinol depsides, orcinol depsidones, $\beta$-orcinol depsidones, and aliphatic acids in medulla (Smith et al. 2009).

Genus Parmelia Ach. (1803) has loosely attached to closely adpressed foliose thallus growing on bark, wood, siliceous rocks or sometimes on soil and is mostly represented by Parmelia saxatilis (L.) Ach or P. sulcata Taylor. Both species form complete or partial rosettes up to 20 $\mathrm{cm}$ diameter. These species have grey-white to gray-green upper surface. Both grow on rocks, walls, roofing tiles from coastal to exposed mountain summits (Smith et al. 2009). P. saxatilis has atranorin, chloroatranorin, and salazinic acid, accessory lobaric acid with or 
without protolichesterinic acid or unidentified fatty acids. This is the most widespread species in the genus, occurring in both hemispheres and known to all lichenologists. For such a common species it has very little morphological and chemical variation. $P$. sulcata has atranorin and chloroatranorin, salazinic acid, consalazinic acid and lobaric acid (Hale 1987).

Yavuz and Cobanoglu (2010) study reports traditional use of Usnea spp. in medicine as mentioned in Liber Medicinalis Almansoris by Rhazes. Within this context, Malhotra et al. (2008) report Parmelia sulcata Taylor (Parmeliaceae) used in the treatment of pulmonary and cranial diseases as well as Parmelia saxatilis (L.) Ach., to treat warts.

The acetone and methanol extract of Parmelia sulcata Taylor manifested antibacterial activity against the majority of species of bacteria tested, in addition to selective antifungal activity (Rankovic et al. 2007). Acetone, chloroform, diethyl ether, methanol, and petroleum ether extracts of Parmelia sulcata and its constituent (salazinic acid) demonstrated antibacterial activity against Aeromonas hydrophila, Bacillus cereus, Bacillus subtilis, Listeria monocytogenes, Proteus vulgaris, Yersinia enterocolitica, Staphylococcus aureus, Streptococcus faecalis, Candida albicans, Candida glabrata, Aspergillus niger, Aspergillus fumigatus, and Penicillium notatum (Candan et al. 2007).

It is supposed that, one of saxicolous-foliose lichens, for example, $P$. saxatilis (L.) Ach or $P$. sulcata Taylor. might be the lichen species Dioscorides mentioned in the first century.

\section{ACKNOWLEDGEMENTS}

The author of this paper thanks to Mrs. Despina DIKOGLOU, Teacher of English from $3^{\text {rd }}$ General Lyceum of Serres, Greece, for her valuable contribution in translations of Greek texts and the draft of this paper.

\section{NOTES}

* on rocks

*** on soil

*** on plants and mosses

\section{REFERENCES}

Aslan A, Güllüce M, Atalan E 2001. A study of antimicrobial activity of some lichens. Bulletin of Pure and Applied Sciences, 20B (1): 23-26.
Aslan A, Güllüce M, Ögütcü H 1999. An investigation on the antimicrobial activity of some lichens. Biyoteknoloji Kükem Dergisi, 22(2):19-26.

Basmadjian KJ 1938. L'Identification des Noms des Plantes du Codex Constantinopolitanus de Dioscoride. Journal Asiatique, 230: 577-621.

Baytop T 1984. Türkiye'de Bitkilerle Tedavi, Gecmiste ve Bugün. 1-520. Istanbul. Istanbul Üniversitesi, Eczacilik Fakültesi Yayinlari. No. 40.

Baytop T 1997. Anazarbali Dioscorides I. yüzyilda yasamis ünlü bir hekim. Sandoz Dergisi, 1: 10-17.

Baytop T 2000. Anadolu Daglarinda 50 Yil, Bir Bitki Avcisinin Gözlemleri. 1-188. Istanbul. Nobel Tip Kitabevi.

Candan M, Yilmaz M, Tay T, Erdem M, Özdemir Türk A. 2007. Antimicrobial activity of extracts of the lichen Parmelia sulcata and its salazinic acid constituent. Zeitschrift für Naturforschung, 62(7-8): 619-621.

Chevallier A 1996. The Encyclopedia of Medicinal Plants. London: Dorling Kindersky.

Cobanoglu G, Yavuz M 2003. Tip Tarihinde Likenlerle Tedavi. Yeni Tip Tarihi Arastirmalari, 9: 37-90.

Du Ruel J 1549. Dioscoridis Libri Octo Graece et Latine Castigationes in Cosdem Libros Paris. From < http:// www.bium.univ-paris $5 . \mathrm{fr} / \mathrm{histmed} / \mathrm{medica} /$ cote? 33477> (Retrieved November 20, 2010).

Dubler C 1951. Los Nombres Árabes de Materia Medica en la Obra del Doctor Laguna. Al - Andalus Madrid/ Granada, 16: 141-164.

Dülger B, Gücin F, Kara A, Aslan A 1997. Usnea Florida (L.) Wigg. Likeninin Antimikrobiyal Aktivitesi. Tr J of Biology, 21: 103-108.

Ferrari G, Ghione M, Ghirardi P 1988. Composition containing usnic acid or its derivatives for the therapeutical control of dental caries particularly for the treatment of the cariogenic dental plaque. Patente No. ZA8704549, P.24.

Gunter RT 1933. The Greek Herbal of Dioscorides. Oxford: Oxford University Press.

Hale M E Jr 1987. A Monograph of the Lichen Genus Parmelia Acharius sensu stricto (Ascomycotina: Pameliaceae. Smithsonian Contributions to Botany Number 66: 1-55. Washington D.C.: Smithsonian Institution Press

Higuchi M, Miura Y, Kinoshita Y, Yamamoto Y, Mayama S 1993. Acne-controlling antibacterial agents containing usnic acids or lichesterinic acids. Japanese Kokai Tokyo Koho, P.3.

Huneck S, Yoshimura I 1996. Identification of Lichen Substances. Berlin: Springer-Verlag.

Kumar SKC, Müller K 1999. Lichen metabolites 1. inhibitory action against leukotriene b4 biosynthesis by a nonredox mechanism. J Nat Prod, 62: 817 - 820.

Kumar SKC, Müller K 2000. Depsides as non-redox inhibitors of leukotriene B4 biosynthesis and $\mathrm{HaCaT}$ cell growth 2. novel analogues of obtusatic acid. Eur J Med Chem, 35: 405-411.

Laguna A 1555. Pedacio Dioscorides Anazarbeo acerca de la materia medicinal y de los venenos mortiferos. Traduzido de lengua Griega en la vulgar Cantellana et illuntrado con claras. Amberes.

Llano G A 1950. Economic Uses of Lichens. Annual Report, Smithsonian Institution Washington D.C., pp. 385-422.

Malhotra S, Subban R, Singh A 2008. Lichens' role in traditional medicine and drug discovery. The Internet 
Journal of Alternative Medicine, 5: (2). ISSN: 15402584 From< http://www.ispub.com/journal/theinternet-journal-of-alternative-medicine/volume-5number-2/lichens-role-in-traditional-medicine-anddrug-discovery.html > (Retrieved November 20, 2010)

Marx J 2001. Anti-inflammatories inhibit cancer growth but how? Science, 291: $581-582$.

Matthioli PA 1568. Di Pedacio Dioscoride Anazarbeo della Materia Medicinale. Venice.

Müller K 2002. Pharmaceutically relevant metabolites from lichens. Applied Microbiology and Biotechnology, 56(1/2): 9-16.

Nash TH 2008. Lichen Biology. $2^{\text {nd }}$ Edition. Cambridge: Cambridge University Press.

Osbaldeston TA 2000. Dioscorides de Materia Medica. Johannesburg, South Africa: Ibidis Press.

Richardson DHS 1991. Lichens and Man. In: DL Hawksworth (Ed.): Frontiers in Mycology. CAB International Kew, pp. 187-210

Rankovic B, Misic M, Sukdolak S. 2007. Evaluation of antimicrobial activity of the lichens Lasallia pustulata, Parmelia sulcata, Umbilicaria crustulosa and Umbilicaria cylindrica. Mikrobiologya, 76(6): 817821.

Romagni JG, Dayan FE 2002. Structural diversity of lichen metabolites and their potential use. In: RK Upadhyay (Ed.): Advances in Microbial Toxin Research and its Biotechnological Exploitation. New York: Kluwer Academic and Plenum Publishers, pp. 151-170.

Saraceni AI 1598. Dioscoridis Anazarbeii Opera quae Extant Omnia ex Noua Interpretatione Lugdunaei (Lyon).
From < http://web2.bium.univ-paris5.fr/livanc/?cote= 00822x01\&p=1\&do=page $>($ Retrieved November 20 , 2010).

Seifert P, Bertrand C 1995. Usnic acid: Anatural preservative from lichens. Cosmet News, 18: $169-172$.

Smith CW, Aptroot A, Coppins BJ, Fletcher A, Gilbert OL, James PW, Wolseley PA 2009. The Lichens of Great Britain and Ireland. London: The British Lichen Society.

Ünver S 1941. Istanbul'da Dioscorides Eserleri ve Artuklular. Dirim, S.1-2: 129-133.

Web01: From<http://dioscorides.usal.es/p2.php?numero= 623> (Retrieved November 20, 2010).

Web02:From<http://www.heilpflanzen-welt.de/buecher/ Dioskurides-Arzneimittellehre/001.htm> (Retrieved November 20, 2010).

Web03:From< http://visualiseur.bnf.fr/CadresFenetre? $\mathrm{O}=\mathrm{COMP}-1 \& \mathrm{I}=232 \& \mathrm{M}=$ imageseule $>$ (Retrieved November 20, 2010).

Wessely C 1906. De Herbarum Nominibus Græcis In Discoridis Codice Constantinopolitano Vindobonensi Arabicis Litteris Expressis. Section 6:1-18. Paper presented in: Actes du XIVe Congrès International des Orientalistes. Algeria, April 19 to 26, 1905.

Yavuz M Cobanoglu G 2010. Ethnological uses and etymology of the word Usnea in Ebubekir Razi's "Liber Almansoris". The British Lichen Society Bulletin, 106: 3-12.

Yildirim V 2003. Dioskorides'in Materia Medica'si ve Türk Islâm Tabâbeti. Yeni Tip Tarihi Arastirmalari, 9: 383480. 